\title{
PERAN LEMBAGA ADAT DALAM PELESTARIAN BUDAYA MASYARAKAT ADAT KAMPUNG NAGA, DESA NEGLASARI, KECAMATAN SALAWU, TASIKMALAYA
}

\section{The Role of Customary Institutions in Curtural Preservation of Indigenous Peoples of Kampung Naga, Neglasari Village, Salawu District, Tasikmalaya}

\author{
Tya Sonia $^{1)}$, Sarwititi Sarwoprasodjo ${ }^{2)}$ \\ Departemen Sains Komunikasi dan Pengembangan Masyarakat, Fakultas Ekologi Manusia, \\ IPB University, Dramaga Bogor 16680, Indonesia \\ E-mail: soniatya22.ts@gmail.com ${ }^{1)}$ dan sarwititi@apps.ipb.ac.id ${ }^{2)}$
}

\begin{abstract}
Preserving culture is an important aspect in the lives of indigenous people because indigenous people are synonymous with lifestyles that are still guided by local customs. The process of cultural preservation of indigenous peoples is inseparable from the important role of traditional institutions. The role of customary institutions has the potential to determine the behavior of indigenous peoples in carrying out their traditional traditions or not. The purpose of this study was to analyze the influence of the role of traditional institutions on cultural preservation by using individual characteristics, namely the age of the respondent as a control variable. This study used a survey method with 60 respondents from Kampung Naga community. Qualitative data was obtained through in-depth interviews with indigenous elders, tour guides, and RT heads of Kampung Naga. Analysis of research data using Mann-Whitney tests. The results showed that with individual characteristics, namely the age of the respondent as a control variable, customary institutions had a significant effect on the cultural preservation of the Kampung Naga indigenous people in terms of behavior patterns, behavior patterns, and material patterns.
\end{abstract}

Keywords: cultural preservation, cultural form, customary institutions, indigenous people, communication function

\begin{abstract}
ABSTRAK
Melestarikan budaya menjadi aspek penting dalam kehidupan masyarakat adat karena masyarakat adat identik dengan gaya hidup yang masih berpedoman pada adat istiadat setempat. Proses pelestarian budaya pada masyarakat adat tidak terlepas dari peran penting lembaga adat. Peran lembaga adat tersebut berpotensi untuk menentukan perilaku masyarakat adat dalam melakukan tradisi adatnya atau tidak. Tujuan penelitian ini adalah menganalisis pengaruh peran lembaga adat terhadap pelestarian budaya dengan menggunakan karakteristik individu yaitu usia responden sebagai variabel kontrol. Penelitian ini menggunakan metode survei dengan responden sebanyak 60 orang masyarakat Kampung Naga. Data kualitatif diperoleh melalui wawancara mendalam kepada sesepuh adat, pemandu wisata, dan ketua RT Kampung Naga. Analisis data penelitian menggunakan uji Mann-Whitney. Hasil penelitian menunjukkan bahwa dengan karakteristik individu yaitu usia responden sebagai variabel kontrol, lembaga adat berpengaruh signifikan terhadap pelestarian budaya masyarakat adat Kampung Naga yang ditinjau dari segi pola bersikap, pola kelakuan, dan pola kebendaan.
\end{abstract}

Kata kunci: lembaga adat, masyarakat adat, pelestarian budaya, wujud budaya, fungsi komunikasi

\section{PENDAHULUAN}

Sebagai negara kepulauan yang memiliki lebih dari 17.000 pulau, Indonesia juga dikenal sebagai negara multicultural yang memiliki lebih dari 250 kelompok etnis dengan lebih dari 500 bahasa yang berbeda. Keanekaragaman budaya ini bertumpu pada keberadaan masyarakat adat yang hidup dan tersebar di seluruh pelosok nusantara. Masyarakat adat merupakan penduduk yang hidup dalam satuansatuan komunitas berdasarkan asal-usul leluhur secara turun-temurun di atas suatu wilayah adat, yang memiliki kedaulatan atas tanah dan kekayaan alam, kehidupan sosial budaya yang diatur oleh hukum adat, dan lembaga adat yang mengelola keberlangsungan kehidupan masyarakatnya (Wuradji 1985).

Menurut UU Republik Indonesia Nomor 06 Tahun 2014, pada pasal 1 (satu) disebutkan bahwa desa dan desa adat adalah kesatuan masyarakat hukum yang memiliki batas wilayah yang berwenang untuk 
mengatur dan mengurus urusan pemerintahan, kepentingan masyarakat setempat berdasarkan prakarsa masyarakat, hak asal-usul, dan/atau hak tradisional yang diakui dan dihormati dalam sistem pemerintahan Negara Kesatuan Republik Indonesia.

Riswar (2013) dalam penelitiannya mengatakan bahwa masyarakat adat merupakan subjek yang paling menentukan apakah suatu kebudayaan yang mereka miliki mengalami perubahan atau tidak. Jika suatu masyarakat adat di zaman yang semakin modern masih dapat memegang teguh adat istiadat mereka, kebudayaan yang mereka miliki akan tetap bertahan. Namun, sebaliknya jika masyarakat adat terbawa arus kemajuan zaman yang semakin modern tanpa memikirkan nasib kebudayaan itu sendiri, kebudayaan tersebut akan mengalami perubahan dan bahkan akan menghilang. Sementara itu, pemerintah merupakan pihak yang paling berwenang dalam menentukan bagaimana pelestarian kebudayaan bisa bertahan hingga nanti. Jika kebudayaan tradisional mengalami pergeseran ke arah kebudayaan modern, kebudayaan tradisional akan menghilang dengan sendirinya. Kekhawatiran akan ancaman tersebut membuat pemerintah mengeluarkan UndangUndang No. 11 Tahun 2010 tentang Cagar Budaya dengan tujuannya sebagai upaya untuk melindungi dan melestarikan budaya Indonesia. Namun, tidak jarang pula kebijakan tersebut menimbulkan polemik di dalam kehidupan masyarakat adat. Salah satu polemik yang ditimbulkan akibat kebijakan pemerintah membuka pariwisata budaya, sering merugikan masyarakat adat. Masyarakat adat sering merasa seperti dijadikan sebagai sebuah tontonan yang berorientasikan materil sehingga bentuk kesakralan yang mereka miliki menjadi sangat terganggu (Setiawan 2011).

Kebiasaan dan kebudayaan merupakan warisan dari nenek moyang yang harus dijaga, salah satunya yaitu dalam hal upacara adat, berpakaian, bentuk rumah, lingkungan sosial, mata pencaharian, termasuk dalam tradisi keagamaan. Para leluhur atau nenek moyang dalam mengimplementasikan suatu kebiasaan yang menjadi tradisi, tentu menimbang baik buruk kebiasaan tersebut dalam bentuk nilai dan norma yang melembaga menjadi aturan hidup, pegangan hidup, atau hukum adat. Hal ini juga terjadi dan berlaku pada masyarakat adat Kampung Naga. Kampung Naga merupakan suatu perkampungan adat yang dihuni oleh sekelompok masyarakat yang sangat kuat dalam memegang budaya dan adat istiadat peninggalan leluhurnya atau nenek moyangnya, dalam hal ini adalah adat Sunda.
Hal-hal yang membuat Kampung Naga ini unik adalah karena masyarakat adat Kampung Naga seperti tidak terpengaruh dengan modernitas dan masih tetap memegang teguh adat istiadat yang secara turun-temurun diwariskan oleh nenek moyang mereka. Selain itu, areal Kampung Naga terbatas hingga tidak memungkinkan lagi untuk mendirikan rumah di kampung itu. Hal itu menjadikan sebagian penduduk Kampung Naga ada yang menyebar ke kampung lain, tetapi tetap menjaga, melestarikan, menghormati, serta melakukan budaya dan adat istiadat nenek moyangnya.

Masyarakat Kampung Naga dibagi menjadi dua, yaitu masyarakat Naga dan masyarakat Sanaga. Masyarakat Naga adalah masyarakat yang masih menetap dan tinggal di daerah wilayah adat. Mereka masih mempertahankan adat istiadat mereka. Sementara itu, masyarakat Sanaga adalah masyarakat Naga yang sudah tidak dapat lagi tinggal di dalam wilayah adat karena keterbatasan lahan, namun mereka masih mengikuti acara-acara adat yang diadakan di Kampung Naga.

Selain itu, karena Kampung Naga merupakan kampung budaya yang masih menjaga adat leluhurnya. Kampung Naga tidak memiliki listrik karena menurut masyarakat Kampung Naga, selain karena arsitektur rumah mereka yang terbuat dari bahan yang mudah terbakar (bagian atap terbuat dari ijuk dan bangunannya terbuat dari bilik dan kayu), yaitu dikhawatirkan juga akan terjadi kecemburuan sosial di antara masyarakat Kampung Naga. Selain itu, hal ini dilakukan untuk menjaga kelestarian lingkungan agar kehidupan modern tidak mudah mengubah kebiasaan dan kebudayaan mereka.

Kehidupan masyarakat Kampung Naga, dalam setiap tindakan, perilaku, kebijakan, serta peraturan dalam kehidupan sehari-hari, tidak terlepas dari peran kelembagaan yang terdapat di Kampung Naga. Terdapat dua kelembagaan di Kampung Naga, yaitu lembaga pemerintahan dan lembaga adat. Lembaga pemerintahan berwenang untuk mengurusi semua aktivitas masyarakat Kampung Naga secara demokratis dan mengacu kepada aturan negara. Lembaga pemerintahan di Kampung Naga terdiri atas RT, RW, dan Kadus (Kepala Dusun). Segala sesuatu yang berhubungan dengan adat istiadat dan aturan hukum adat diurusi dan diawasi oleh lembaga adat. Lembaga adat terdiri atas seorang kuncen, punduh, dan lebe.

Soemantadiredja (2014) dalam penelitiannya menjelaskan bahwa para pemimpin adat dalam hal 
ini adalah lembaga adat pada umumnya memiliki sesuatu yang dianggap lebih yang terdapat pada dirinya yang tidak dimiliki oleh orang lain. Seperti kharisma yang terdapat dalam diri yang mampu membuat orang patuh dan mendengarkan sesuatu yang dikatakan. Menurut Kartodirjo (1984), pemimpin informal cenderung dikategorikan sebagai pemimpin kharismatik yang dianggap memiliki kekuatan-kekuatan yang bersifat luar biasa yang diberikan hanya kepada segelintir manusia untuk memilikinya. Definisi pemimpin karismatik adalah suatu kemampuan seseorang dalam memimpin untuk mendapat kehormatan, ketaatan serta kehebatan terhadap dirinya sebagai sumber dari kekuasaan tersebut. Menurut Kartodirjo (1984), di dalam kepemimpinan, para pemimpin kharismatik terdapat suatu interaksi dengan kondisi pemimpin itu mengemukakan dan para pengikutnya menerima, tentang pengenalan dirinya sebagai pemimpin mereka yang telah ditakdirkan. Pemimpin kharismatik bukan hanya sekadar memiliki kemampuan memimpin untuk mendapat kekuasaan, namun pemimpin kharismatik juga memperjuangkan kesejahteraan umum dalam menegakkan keadilan dan kebenaran, serta menjaga keselamatan bagi warganya.

Pelestarian budaya masyarakat adat dimaksudkan untuk menjaga agar nilai, adat-istiadat dan kebiasaan yang telah tumbuh, hidup dan berkembang dalam kehidupan masyarakat adat, tetap lestari dan tidak hilang. Selain itu, pelestarian budaya penting dilakukan untuk membatasi pengaruh modernisasi yang berpotensi menghancurkan ikatan nilai tradisi seperti kekeluargaan, gotong royong, nilai-nilai keagamaan, adat-kebiasaan lokal, maupun pranata budaya yang sebenarnya telah berakar dalam formasi kehidupan sosial. Berdasarkan latar belakang di atas, menarik untuk diteliti terkait bagaimana peran lembaga adat dalam proses pelestarian budaya pada masyarakat adat Kampung Naga, Desa Neglasari, Kecamatan Salawu, Tasikmalaya.

Tujuan penelitian terkait "Peran Lembaga Adat dalam Pelestarian Budaya Masyarakat Adat Kampung Naga", yaitu:

1. Menganalisis peran lembaga adat dalam menyosialisasikan budaya kepada masyarakat adat Kampung Naga

2. Mengidentifikasi perilaku yang ditunjukkan oleh masyarakat adat dalam melestarikan budaya masyarakat adat.

\section{PENDEKATAN TEORITIS}

\section{Karakteristik Individu}

Pamungkas (2012) mengatakan bahwa suatu karakteristik individu dapat membentuk dan memengaruhi suatu komunitas. Usia, tingkat pendidikan, jenis kelamin, dan jenis pekerjaan memang memengaruhi perilaku individu dalam suatu komunitas adat. Karakteristik individu menurut Lionberger (1960) dikutip Walters et al.(2005) menyatakan bahwa karakteristik individu yang perlu diperhatikan adalah umur, tingkat pendidikan, dan karakteristik psikologi. Karakteristik psikologi yang dimaksud antara lain adalah rasionalitas, fleksibilitas mental, dogmatisme, orientasi terhadap usaha tani dan kecenderungan mencari informasi.

\section{Konsep Peran}

Menurut Wulansari (2009) peran adalah konsep tentang apa yang harus dilakukan oleh individu dalam masyarakat dan meliputi tuntutan-tuntutan perilaku dari masyarakat terhadap seseorang dan merupakan perilaku individu yang penting bagi struktur sosial masyarakat. Soekanto (2012) berpendapat bahwa peran merupakan aspek dinamis kedudukan (status) apabila seseorang melaksanakan hak dan kewajiban sesuai dengan kedudukannya, maka dia telah menjalankan suatu peran.

Menurut Soekanto (2012), peran yang melekat pada diri seseorang harus dibedakan dengan posisi dalam pergaulan kemasyarakatan. Posisi seseorang dalam masyarakat (social position) merupakan unsur statis yang menunjukkan tempat individu pada organisasi masyarakat. Peran lebih banyak menunjuk pada fungsi, penyesuaian diri, dan sebagai suatu proses.

Berdasarkan pengertian di atas dapat disimpulkan bahwa pengertian peran adalah pola perilaku kolektif yang diharapkan oleh orang lain terhadap seseorang sebagai wujud dari suatu kedudukan (status) untuk menjalankan hak dan kewajibannya sesuai dengan apa yang diharapkan oleh anggota-anggota lain dari masyarakatnya. Setiap orang mempunyai perannya masing-masing yang berasal dari pola kehidupannya. Hal itu sekaligus berarti bahwa peran menentukan apa yang dibuatnya bagi masyarakat serta kesempatan-kesempatan atau respon apa yang diberikan oleh masyarakat kepadanya.

\section{Konsep Adat dan Lembaga Adat}

Menurut Seokanto (2012), adat atau kebiasaan adalah tingkah laku seseorang yang terus-menerus 
dilakukan dengan cara tertentu dan diikuti oleh masyarakat dalam waktu yang lama. Unsur-unsur terciptanya adat adalah adanya tingkah laku seseorang, dilakukan secara terus menerus, adanya dimensi waktu, dan diikuti oleh orang lain atau masyarakat. Koentjaraningrat (1979) mengatakan bahwa adat adalah suatu bentuk perwujudan dari kebudayaan, kemudian adat digambarkan sebagai tata kelakuan. Adat merupakan sebuah norma atau aturan yang tidak tertulis, akan tetapi keberadaannya sangat kuat dan mengikat sehingga siapa saja yang melanggarnya akan dikenakan sanksi yang cukup keras. Adat istiadat dapat mencerminkan jiwa suatu bangsa karena adat istiadat merupakan kepribadian bangsa.

Menurut Anwar dan Adang (2013), lembaga adat adalah suatu organisasi kemasyarakatan adat yang dibentuk oleh suatu masyarakat hukum adat tertentu, mempunyai wilayah tertentu dan harta kekayaan sendiri, serta berhak dan berwenang untuk mengatur dan mengurus serta menyelesaikan hal-hal yang berkaitan dengan adat. Menurut ilmu budaya, lembaga adat diartikan sebagai suatu bentuk organisasi adat yang tersusun relatif tetap atas polapola kelakuan, peran, dan relasi-relasi yang terarah dan mengikat individu, mempunyai otoritas formal, dan sanksi hukum adat guna tercapainya kebutuhankebutuhan dasar.

Peran lembaga adat adalah suatu perilaku atau aktivitas yang dilakukan berdasarkan kedudukan seseorang sesuai dengan hak dan kewajibannya dalam suatu masyarakat adat mengenai segala urusan yang berhubungan dengan adat istiadat setempat. Menurut Ntonzima L dan Bayat MS (2012) dalam penelitiannya mengatakan bahwa lembaga adat berperan dalam 1). Memimpin ritual keagamaan, 2). Memberi informasi, 3). Memelihara warisan leluhur, dan 4). Menjaga alam.

\section{Konsep Kebudayaan}

Menurut Koentjaraningrat (1979), kebudayaan adalah keseluruhan sistem gagasan, tindakan, dan hasil karya manusia dalam rangka kehidupan masyarakat yang dijadikan milik manusia dengan cara mempelajarinya. Menurut Soekanto (2012) kebudayaan adalah kompleks yang mencakup pengetahuan, kepercayaan, kesenian, moral, hukum, adat istiadat, dan kemampuan-kemampuan serta kebiasaan-kebiasaan yang didapatkan oleh manusia sebagai anggota masyarakat.
Seorang antropolog yaitu C. Kluckhohn dikutip oleh Soekanto (2012) telah menguraikan unsur-unsur kebudayaan universal, mulai dari hal yang abstrak sampai hal yang paling konkret, yaitu (1) sistem religi, (2) kesenian, (3) sistem pengetahuan, (4) organisasi sosial, (5) sistem ekonomi, (6) sistem teknologi, dan (7) bahasa. Menurut Koentjaraningrat (1979) dan Redfield (1956), setiap unsur kebudayaan universal memiliki tiga wujud kebudayaan, yaitu:

1. Wujud idiil (pola bersikap), yaitu kompleks gagasan dan nilai-nilai,

2. Wujud aktivitas (pola kelakuan), yaitu suatu kompleks tindakan berpola (terorganisasi dan terstruktur) dari manusia dalam masyarakat, dan

3. Wujud fisik (pola sarana atau kebendaan), yaitu benda-benda hasil karya manusia.

Wujud pertama berbentuk abstrak sehingga tidak dapat dilihat dengan indera penglihatan. Wujud ini terdapat di dalam pikiran masyarakat. Ide atau gagasan banyak hidup bersama dengan masyarakat. Gagasan itu selalu berkaitan dan tidak bisa lepas antara yang satu dengan yang lainnya. Keterkaitan antargagasan ini disebut sebagai suatu sistem. Wujud kebudayaan yang kedua disebut dengan sistem sosal. Sistem sosial dijelaskan Koentjaraningkat sebagai keseluruhan aktifitas manusia atau segala bentuk tindakan manusia yang berinteraksi dengan manusia lainnya. Aktivitas ini dilakukan setiap waktu dan membentuk pola-pola tertentu berdasarkan adat yang berlaku dalam masyarakat tersebut. Kemudian wujud ketiga kebudayaan disebut dengan kebudayaan fisik. Wujud kebudayaan ini bersifat konkret karena merupakan benda-benda dari segala hasil cipta, karya, tindakan, aktivitas, dan perbuatan manusia dalam masyarakat.

\section{Pelestarian Budaya}

Widjaja (1986) mengartikan pelestarian sebagai kegiatan atau yang dilakukan secara terus menerus, terarah dan terpadu guna mewujudkan tujuan tertentu yang mencerminkan adanya sesuatu yang tetap dan abadi, bersifat dinamis, luwes, dan selektif (Jacobus, 2006:115). Mengenai pelestarian budaya lokal, Lawton, Denis dan Robert Cowen (2001) mengemukakan bahwa pelestarian norma lama bangsa (budaya lokal) adalah mempertahankan nilainilai seni budaya, nilai tradisional dengan mengembangkan perwujudan yang bersifat dinamis, serta menyesuaikan dengan situasi dan kondisi yang selalu berubah dan berkembang. 
Menjadi sebuah ketentuan dalam pelestarian budaya akan adanya wujud budaya, artinya bahwa budaya yang dilestarikan memang masih ada dan diketahui, walaupun pada perkembangannya semakin terkikis atau dilupakan. Pelestarian itu hanya bisa dilakukan secara efektif manakala benda yang dilestarikan itu tetap digunakan dan tetap ada dijalankan. Jika budaya itu tak lagi digunakan maka budaya itu akan hilang dan jika alat-alat itu tak lagi digunakan oleh masyarakat, alat-alat itu dengan sendirinya akan hilang.

\section{Masyarakat Adat}

Menurut Poerwanto (2000), masyarakat adat adalah suatu komunitas yang mendiami wilayah adat yang memiliki kearifan lokal dan pengentahuan tradisi yang bermanfaat bagi penetapan dan pengaturan fungsi hutan. Kearifan lokal ini merupakan salah satu dari pola adaptasi yang dikembangkan oleh masyarakat adat agar mampu memanfaatkan lingkungan sekitar demi kepentingannya, baik untuk memperoleh bahan pangan, menghindari diri dari bahaya, serta dapat dikatakan juga sebagai bentuk penjagaan terhadap ekosistemnya agar tetap mempertahankan hidupnya. Masyarakat adat menurut AMAN (Aliansi Masyarakat Adat Nasional) adalah komunitas-komunitas yang hidup berdasarkan asal-usul leluhur secara turun temurun di atas suatu wilayah adat, yang memiliki kedaulatan atas tanah dan kekayaan alam, kehidupan sosial budaya yang diatur oleh hukum adat dan lembaga adat yang mengelola keberlangsungan kehidupan masyarakatnya.

Masyarakat adat menurut UU No. 32 Tahun 2009 tentang Perlindungan dan Pengelolaan Lingkungan Hidup adalah kelompok masyarakat yang secara turun-temurun bermukim di wilayah geografis tertentu karena adanya ikatan pada asal-usul leluhur, adanya hubungan yang kuat dengan lingkungan hidup, serta adanya sistem nilai yang menentukan pranata ekonomi, politik, sosial, dan hukum. Keraf (2010), menyebutkan beberapa ciri yang membedakan masyarakat adat dari kelompok masyarakat lain, yaitu:

1. Mereka mendiami tanah-tanah milik nenek moyangnya, baik seluruhnya atau sebagian.

2. Mereka mempunyai garis keturunan yang sama, yang berasal dari penduduk asli daerah tersebut.

3. Mereka mempunyai budaya yang khas, yang menyangkut agama, sistem suku, pakaian, tarian, cara hidup, peralatan hidup sehari-hari, termasuk cara untuk mencari nafkah.
4. Mereka mempunyai bahasa sendiri.

5. Biasanya hidup terpisah dari kelompok masyarakat lain dan menolak atau bersikap hatihati terhadap hal-hal baru yang berasal dari luar komunitasnya.

\section{Kerangka Pemikiran}

Kerangka pemikiran dalam penelitian ini menjelaskan antarvariabel penelitian yang berpengaruh terhadap pelestarian budaya pada masyarakat adat Kampung Naga. Budaya dan tradisi masyarakat adat merupakan suatu aset bangsa Indonesia. Oleh karena itu, budaya perlu untuk dilestarikan. Jika tidak, dikhawatirkan suatu tradisi atau budaya bangsa sebagai bentuk keberagaman dan kemajemukan Indonesia akan punah. Maka dari itu, semua pihak harus berperan untuk tetap mempertahankan dan melestarikan nilai-nilai kebudayaan pada masyarakat adat.

Penelitian ini menggunakan karakteristik responden sebagai variabel kontrol. Pamungkas (2012) mengatakan bahwa suatu karakteristik individu dapat membentuk dan memengaruhi suatu komunitas. Karakteritik responden yang dimaksud terdiri atas usia, jenis kelamin, jenis pekerjaan, dan tingkat pendidikan. Karakteristik responden yang paling memengaruhi peran lembaga adat dan pelestarian budaya di Kampung Naga yaitu usia responden. Usia responden tersebut dibagi menjadi dua golongan, yaitu golongan usia muda dan golongan usia tua. Pembagian golongan usia menurut adat di Kampung Naga yaitu usia muda (13-35 tahun) dan usia tua (>35 tahun).

Lembaga adat yang terdapat di Kampung Naga terdiri atas kuncen (yang biasa disebut dengan ketua adat), lebe, dan punduh. Lembaga adat tersebut memiliki peran yang lebih dominan dalam kehidupan masyarakat adat Kampung Naga dalam proses pelestarian budaya meskipun dalam prosesnya peran lembaga adat dan lembaga pemerintahan saling bersinergi satu sama lain untuk tujuan keharmonisan masyarakat adat Kampung Naga. Menurut Ntonzima L dan Bayat MS (2012), peran lembaga adat dalam proses pelestarian budaya yaitu: 1) Memimpin ritual adat dan keagamaan, 2) Memberikan informasi, 3) Memelihara warisan tradisi leluhur, dan 4) Menjaga alam. Peran lembaga adat dapat memengaruhi perilaku masyarakat adat dalam melestarikan budaya.

Hasil dari melaksanakan pelestarian budaya tersebut dapat dilihat dari wujud nyata atau konkret suatu 
tradisi adat masih ada dan masih dilaksanakan oleh masyarakatnya hingga saat ini dan seterusnya. Menurut Koentjaraningrat (1979) dan Redfield (1956), setiap unsur universal kebudayaan memiliki tiga wujud, yaitu : 1) Wujud idiil (pola bersikap), yaitu kompleks, gagasan, dan nilai-nilai, 2) Wujud aktivitas (pola kelakuan), yaitu suatu kompleks tindakan berpola (terorganisasi dan terstruktur) dari manusia dalam masyarakat, dan 3) Wujud fisik (pola sarana atau kebendaan), yaitu benda-benda hasil karya manusia yang diwariskan dari generasi sebelumnya ke generasi berikutnya.

\section{Keterangan}

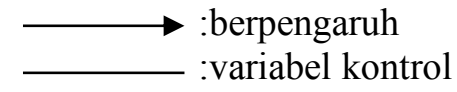

Gambar 1 Kerangka pemikiran peran lembaga adat dalam pelestarian budaya masyarakat adat Kampung Naga

Variabel pada penelitian ini terdiri atas peran lembaga adat sebagai variabel $\mathrm{X}$ dan wujud konkret kebudayaan sebagai variabel $\mathrm{Y}$. Indikator peran lembaga adat dihubungkan dengan wujud konkret kebudayaan untuk melihat adanya pengaruh atau tidak. Hasil dari pengaruh peran lembaga adat tersebut dapat dilihat dari perilaku masyarakat adat Kampung Naga dari segi pola bersikap, pola kelakuan, dan pola sarana atau kebendaan yang masih ada sampai saat ini. Penelitian ini menggunakan karakteristik individu yaitu usia responden sebagai variabel kontrol dengan tujuan melihat ada perbedaan pengaruh atau tidak antara responden dengan golongan usia tua dan responden dengan golongan usia muda. Kerangka pemikiran penelitian ini disajikan pada Gambar 1 berikut.

\section{METODE PENELITIAN}

Penelitian ini dilakukan dengan menggunakan pendekatan kuantitatif yang didukung dengan data kualitatif. Metode kuantitatif dilakukan dengan metode survei terhadap responden, yaitu masyarakat Kampung Naga sebanyak 60 orang. Penelitian survei merupakan penelitian yang mengambil sebagian unsur dari populasi dengan menggunakan kuesioner sebagai alat pengumpul data primer (Effendi dan Tukiran 2012). Pendekatan kuantitatif digunakan untuk mencari pengaruh antarvariabel yang akan diuji yaitu peran lembaga adat dan pelestarian budaya masyarakat adat Kampung Naga, dengan menggunakan usia responden sebagai variabel kontrol. Sementara metode kualitatif dilakukan melalui metode wawancara mendalam kepada informan. Pendekatan kualitatif digunakan untuk memperoleh informasi yang lebih mendalam dari informan megenai sejarah berdirinya Kampung Naga, pola kelembagaan di Kampung Naga dan pelestarian budaya Kampung Naga. Hasil yang didapatkan dari wawancara mendalam digunakan untuk menyempurnakan pertanyaan dalam kuesioner. Selain itu penelitian ini bersifat diskriptif yang berguna untuk membuat penjelasan secara sistematis, faktual, dan akurat mengenai fakta-fakta yang diperoleh selama penelitian.

Data kuantitaitf pada penelitian ini diolah, menggunakan Microsoft Excel 2013 dan IBM SPSS Statistics 16 for Windows. Data dianalisis dengan menggunakan tabel frekuensi untuk melihat data awal responden pada masing-masing variabel secara tunggal menggunakan aplikasi Microsoft Excel 2013. Kemudian, IBM SPSS Statistics 16 for Windows digunakan untuk uji statistik dan untuk menguji ada atau tidaknya pengaruh peran lembaga adat terhadap pelestarian budaya pada masyarakat adat Kampung Naga. Data kualitatif dianalisis dengan merangkum hasil wawancara mendalam dengan para responden dan informan dengan melakukan proses pemilihan dan penyederhanakan data hasil wawancara mendalam, lalu menyusun informasi dan data yang diperoleh menjadi serangkaian kata-kata atau narasi yang mudah dibaca ke dalam sebuah laporan, lalu melakukan verifikasi, yaitu penarikan kesimpulan dari hasil yang telah diolah untuk mendukung data kuantitatif. 
Penelitian ini dilakukan di Kampung Naga, Kabupaten Tasikmalaya. Pemilihan lokasi penelitian akan dilakukan secara sengaja (purposive). Penelitian di lapangan dilaksanakan dalam jangka waktu satu bulan, yaitu pada bulan Maret sampai dengan April 2019.Unit analisis pada penelitian ini yaitu individu. Populasi dalam penelitian ini adalah warga Kampung Naga yang memiliki usia di atas 13 tahun dengan total populasi sebanyak 242 orang. Responden dalam penelitian ini diambil dengan metode pengambilan sampel acak sederhana (simple random sampling). Kemudian ditentukan sampel penelitian yang berjumlah 60 responden, yang dibedakan menurut jenis kelamin dan yang mempunyai usia di atas 13 tahun. Responden tersebut terdiri atas 30 orang laki-laki dan 30 orang perempuan. Data kualitatif diperoleh dengan melakukan observasi lapang dan wawancara mendalam kepada informan menggunakan panduan pertanyaan wawancara mendalam, untuk memahami secara mendalam dan rinci mengenai sejarah terbentuknya Kampung Naga dan pengalaman masyarakat ketika melaksanakan tradisi adat. Pemilihan informan dalam penelitian ini dilakukan secara langsung dan purposive (sengaja). Informan pada penelitian ini ialah pemandu wisata, ketua RT Kampung Naga, kuncen (ketua adat), lebe adat, dan punduh adat,

Penelitian ini memiliki dua jenis data, yaitu primer dan data sekunder. Data primer yang diperoleh dari kuesioner bertujuan mendapatkan informasi terkait variabel yang diuji yaitu peran lembaga adat dalam pelestarian budaya pada masyarakat adat. Data primer yang dihasilkan dari wawancara mendalam menghasilkan data pendukung untuk melengkapi data kuantitatif. Observasi lapang dilakukan dengan cara mengikuti secara langsung kegiatan masyarakat di Kampung Naga. Data sekunder didapatkan dengan melihat data monografi Kampung Naga.

\section{HASIL DAN PEMBAHASAN}

\section{Kondisi Kampung Naga}

Kampung Naga terdiri atas satu Rukun Tetangga (RT). Jumlah penduduk Kampung Naga yaitu sebanyak 293 jiwa yang terdiri atas 147 laki-laki dan 146 perempuan dengan jumlah kepala keluarga sebanyak 100 Kepala Keluarga (KK). Kampung Naga terbagi menjadi dua wilayah, yaitu wilayah Naga dan wilayah Sanaga (Suganda 2006). Masyarakat yang berada di wilayah Naga merupakan anggota masyarakat yang masih menetap di wilayah Kampung dan masih menaati seluruh aturan adat yang berlaku, sedangkan masyarakat yang berada di wilayah Sanaga masih merupakan kerabat dari anggota masyarakat Naga, namun tidak dapat tinggal di wilayah adat Kampung Naga karena terbatasnya lahan. Masyarakat Sanaga, meskipun menetap di luar wilayah adat Kampung Naga, namun masih mengikuti seluruh tradisi adat Kampung Naga.

Adat istiadat yang ada di Kampung Naga merupakan suatu aturan yang sangat sakral sehingga harus dijalani dengan baik. Adat istiadat yang ada di Kampung Naga di antaranya yaitu menyepi, upacara adat hajat sasih, penanaman padi Janli, larangan memasuki hutan larangan dan hutan keramat, aturan bangunan rumah, dan mengikuti seluruh perkataan sesepuh atau orang tua. Pola kelembagaan di Kampung Naga terdiri atas dua lembaga yang masing-masing memiliki tugas dan fungsi yang berbeda, yaitu lembaga pemerintah dan lembaga adat. Peran lembaga pemerintah dan lembaga adat saling bersinergi satu sama lain untuk tujuan keharmonisan Kampung Naga. Lembaga adat memiliki wewenang dalam sistem adat jika berhubungan dengan sistem pemerintahan desa pasti akan menaatinya. Lembaga adat terdiri atas kuncen, lebe, dan punduh. Lembaga pemerintah yang terdapat di Kampung Naga terdiri atas RT, RW dan Kadus (Kepala Dusun).

\section{Karakteristik Responden Warga Kampung Naga}

Sebagian besar masyarakat Kampung Naga termasuk ke dalam golongan dewasa tua karena sebagian besar dari mereka berusia di atas 35 tahun. Mayoritas masyarakat Kampung Naga memiliki tingkat pendidikan tamatan SD/Sederajat. Petani merupakan pekerjaan utama masyarakat Kampung Naga karena profesi petani merupakan suatu profesi yang telah diwariskan oleh para sesepuh atau leluhur mereka dan masyarakat Kampung Naga memiliki keharusan untuk tetap menjaganya.

\section{Lembaga Adat Kampung Naga}

Lembaga adat adalah lembaga kemasyarakatan baik yang disengaja dibentuk maupun yang secara wajar telah tumbuh dan berkembang di dalam sejarah masyarakat atau dalam suatu masyarakat hukum adat tertentu, mempunyai wilayah hukum dan hak atas harta kekayaan di dalam hukum adat tersebut, serta berhak dan berwenang untuk mengatur, mengurus, dan menyelesaikan berbagai permasalahan 
kehidupan yang berkaitan dengan dan mengacu pada adat istiadat dan hukum adat yang berlaku. Lembaga adat di Kampung Naga terdiri atas ketua adat yang disebut dengan kuncen, lebe adat, dan punduh adat. Setiap anggota lembaga adat tersebut memiliki perannya masing-masing dalam kehidupan bermasayarakat di Kampung Adat Naga.

Ketua adat atau yang biasa disebut dengan kuncen, adalah juru kunci (tempat-tempat keramat) yang juga mengetahui riwayat tempat yang dijaganya. Kuncen memiliki wewenang untuk menyelesaikan masalah yang dihadapi masyarakatnya, baik yang berhubungan dengan adat maupun dengan tugastugas pemerintahan setempat. Tugas lain dari kuncen adalah bertanggung jawab unuk menjaga, melaksanakan, dan memimpin acara-acara adat.

Lebe adat memiliki peran yaitu mengatur persoalan keagamaan dalam kehidupan masyarakat Kampung Naga. Persoalan-persoalan keagamaan tersebut seperti memimpin ritual-ritual yang terkait dengan ajaran agama Islam, memimpin upacara pernikahan, maulidan, upacara kematian, dimulai dari awal yaitu memandikan jenazah hingga tahap akhir yaitu menguburkan jenazah dan memimpin acara tahlilan, dan memimpin acara keagamaan lainnya.

Punduh adat mengatur laku lampah masyarakat dalam mengatur kehidupan kemasyarakatan dan mengoordinasi menjaga ketertiban kampung adat. Selain itu, punduh adat juga memiliki wewenang untuk menegur dan memberi sanksi jika ada masyarakat yang perilakunya tidak sesuai dengan ketentuan adat.

\section{Peran Lembaga Adat Kampung Naga dalam Memimpin Ritual Adat dan Keagamaan}

Memimpin ritual adat dan keagamaan merupakan salah satu bidang tanggung jawab dari lembaga adat dengan melakukan serangkaian kegiatan yang dilaksanakan dengan tujuan simbolis sebagai hubungan dengan Sang Pencipta. Hal ini dapat dilihat dari frekuensi lembaga adat Kampung Naga melakukan tugas dan tanggung jawabnya dalam hal adat dan keagamaan yang diukur dari sudut pandang warga Kampung Naga.

Berdasarkan hasil uji Mann Withney dengan menggunakan SPSS, bahwa peran kuncen memiliki pengaruh yang lebih besar secara signifikan terhadap responden golongan usia tua dengan nilai rata-rata 4,82 dibanding dengan responden golongan usia muda. Namun, untuk peran lebe dalam mengajak masyarakat untuk melakukan sholat berjamaah di masjid memiliki pengaruh yang lebih besar secara signifikan terhadap responden usia muda dengan nilai 3,42, dibanding dengan responden usia tua.

Hal ini sesuai pula dengan penelitian yang dilakukan oleh Miharja (2015), yang mengatakan bahwa lembaga adat berperan dalam hal memimpin ritual adat dan keagamaan. Tujuan dari memimpin ritual adat dan keagamaan tersebut sebagai salah satu upaya untuk melestarikan nilai-nilai budaya leluhur.

\section{Peran Lembaga Adat dalam Memberi Informasi}

Memelihara warisan tradisi leluhur merupakan suatu usaha untuk melestarikan benda atau atribut tak berbenda yang merupakan jati diri, kebiasaan, adat istiadat, tradisi, bahasa suatu masyarakat adat yang diwariskan dari generasi sebelumnya ke generasi berikutnya. Hal ini dapat dilihat dari frekuensi lembaga adat mengajak masyarakat untuk bersamasama melaksanakan tradisi adat Kampung Naga.

Berdasarkan hasil uji Mann Withney dengan menggunakan SPSS, bahwa peran lembaga adat (dalam hal ini kuncen) dalam memberi tahu mengenai waktu pelaksanaan acara-acara adat memiliki pengaruh yang lebih besar terhadap responden golongan usia tua dibanding kepada responden golongan usia muda. Kuncen memberi tahu informasi kepada masyarakat Kampung Naga mengenai waktu pelaksanaan ziarah ke makam keramat, memberi tahu waktu pelaksanaan penanaman padi Janli, memberi tahu waktu pelaksanaan upacara adat hajat sasih, dan memberi tahu waktu alternatif pelaksanaan upacara adat hajat sasih.

\section{Peran Lembaga Adat dalam Menjaga Warisan Tradisi Leluhur}

Memelihara warisan tradisi leluhur merupakan suatu usaha untuk melestarikan benda atau atribut tak berbenda yang merupakan jati diri, kebiasaan, adat istiadat, tradisi, bahasa suatu masyarakat adat yang diwariskan dari generasi sebelumnya ke generasi berikutnya. Hal ini dapat dilihat dari frekuensi lembaga adat mengajak masyarakat untuk bersamasama melaksanakan tradisi adat Kampung Naga.

Berdasarkan hasil uji Mann Withney dengan menggunakan SPSS, bahwa peran kuncen dalam mengajak warga untuk berziarah ke makam keramat memiliki pengaruh yang lebih besar secara signifikan terhadap responden golongan usia tua dengan nilai rata-rata yaitu 2,51 dibanding dengan responden golongan usia muda. Peran kuncen dalam 
mengajak warga untuk melaksanakan penanaman padi Janli memiliki pengaruh yang lebih besar secara signifikan terhadap responden golongan usia tua dengan nilai rata-rata yaitu 4,20 dibanding dengan responden golongan usia muda.

Hal ini sesuai pula dengan penelitian yang dilakukan oleh Hindaryatiningsih (2016), yang mengatakan bahwa pemimpin adat berperan dalam hal menjaga nilai-nilai budaya lokal dalam suatu tradisi adat. Melestarikan nilai-nilai budaya tersebut disosialisasikan ke dalam tiga bentuk tradisi lokal, diantaranya yaitu nilai budaya dalam tradisi kepercayaan, nilai budaya dalam ritual keagamaan Islam, dan nilai budaya dalam tradisi siklus hidup manusia

\section{Peran Lembaga Adat dalam Menjaga Alam}

Menjaga alam merupakan suatu bentuk tindakan yang bertujuan menjaga keseimbangan alam sekitar. Hal ini dapat dilihat dari frekuensi lembaga adat memberi tahu dan mengajak masyarakat adat Kampung Naga untuk melestarikan alam sekitar karena kehidupan masyarakat Kampung Naga masih sangat bergantung pada hasil alam sehingga tidak akan terjadi kerusakan pada lingkungan Kampung Naga.

Berdasarkan hasil uji Mann Withney dengan menggunakan SPSS, bahwa peran lembaga adat dalam mengajak masyarakat bergotong royong membersihkan lingkungan memiliki pengaruh yang lebih besar secara signifikan terhadap responden dengan golongan usia tua dengan nilai rata-rata 4,41. Namun, peran lembaga adat dalam hal ini kuncen dalam menjelaskan mengenai aturan rumah yang diharuskan terbuat dari bahan dasar alam memiliki pengaruh yang lebih besar secara signifikan terhadap responden golongan muda dibanding responden golongan usia tua.

\section{Pengaruh Peran Lembaga Adat terhadap Wujud Konkret Budaya Masyarakat Adat Kampung Naga}

Pelestarian budaya pada masyarakat adat Kampung Naga tidak terlepas dari peran lembaga adat. Masyarakat merasa bahwa lembaga adat, yang terdiri atas kuncen, lebe, dan punduh sebagai pemimpin dan sesepuh adat Kampung Naga, mampu meningkatkan ketaatan masyarakat Kampung Naga dalam melaksanakan dan melestarikan budaya dan tradisi adat. Lembaga adat menjadi panutan dan mampu memberikan contoh, memberi motivasi, memberi semangat, memberi solusi, dan bertanggung jawab dalam melaksanakan acara-acara adat di Kampung Naga. Perilaku melestarikan budaya merupakan suatu bentuk tindakan yang dilakukan oleh masyarakat adat yang mencerminkan ketaatan terhadap adat. Hasil dari melaksanakan budaya tersebut dapat dilihat dari wujud nyata atau konkret suatu tradisi adat masih ada dan masih dilaksanakan oleh masyarakat adat Kampung Naga hingga saat ini dan seterusnya.

Hipotesis penelitian ini adalah dengan karakteristik individu warga sebagai variabel kontrol, lembaga adat berpengaruh signifikan terhadap pelestarian wujud konkret budaya masyarakat adat Kampung Naga, yang ditinjau dari segi wujud idiil (pola bersikap), wujud aktivitas (pola kalakuan), dan wujud fisik (pola sarana atau kebendaan). Karakteristik individu yang dimaksud yaitu usia responden. Usia responden tersebut dibagi menjadi dua golongan, yaitu golongan usia muda dan golongan usia tua. Pembagian golongan usia tersebut bdilakukan menurut adat di Kampung Naga, yaitu usia muda (13-35 tahun) dan usia tua ( $>35$ tahun).

Berdasarkan hasil uji Mann Withney dengan menggunakan SPSS, menunjukkan bahwa hipotesis awal penelitian ini terbukti. Hal ini ditunjukkan dengan nilai signifikansi wujud idiil sebesar 0,001 , nilai signifikansi wujud aktivitas sebesar 0,018 , dan nilai signifikansi wujud fisik sebesar 0,000 . Nilai signifikan ini menunjukkan besaran yang lebih kecil dari nilai $p$-value yaitu 0,05 . Hal ini dapat terjadi karena peran lembaga adat memiliki pengaruh yang besar dalam menyosialisasikan kebudayaan pada masyakat adat Kampung Naga. Hal tersebut dapat dilihat dari perilaku masyarakat Kampung Naga yang taat dalam melaksanakan acara-acara adat dan aturan adat yang berlaku di Kampung Naga. Selain itu, benda-benda yang menjadi warisan leluhur atau nenek moyang mereka juga masih dilestarikan dan dipertahankan hingga saat ini.

Berdasarkan data di lapang, terdapat perbedaan yang signifikan antara responden golongan usia muda dan responden golongan usia tua dalam hal wujud idiil. Responden dengan golongan usia tua sudah lebih memahami dan mengerti mengenai seluruh aturan adat yang berlaku di Kampung Naga sehingga mereka menjadikan aturan adat tersebut sebagai pedoman dalam berperilaku dalam kehidupan sehari-hari. Namun, responden dengan golongan usia muda belum terlalu 
memahami dan mengerti mengenai aturan adat dan sanksi adat yang berlaku di Kampung Naga.

Hasil uji Mann Withney tersebut juga menunjukkan adanya perbedaan yang signifikan antara responden golongan usia muda dengan responden golongan usia muda dalam hal wujud aktivitas. Jika diteliti lebih lanjut, di zaman modern seperti sekarang ini, banyak terdapat perubahan dalam perilaku masyarakat adat Kampung Naga yang merupakan indikasi dari mulai pudarnya keaslian Kampung Naga. Misalnya dalam melakukan aturan adat mengenai penyimpanan padi di leuit ageung. Golongan usia muda sudah sedikit yang melakukan penyimpanan hasil panen di leuit ageung. Mereka kini lebih berorientasi pada ekonomi sehingga padi hasil panen tersebut dijual. Namun, golongan usia tua masih banyak yang melakukan aturan adat tersebut. Selain itu, karena banyaknya wisatawan asing maupun domestik yang sering berkunjung ke Kampung Naga, menjadikan Kampung Adat Naga seolaholah dikomersialkan.

Hasil uji Mann Withney juga menunjukkan adanya perbedaan yang signifikan antara responden golongan usia muda dengan responden golongan usia tua dalam hal wujud fisik. Pola kebendaan yang paling menonjol perbedaannya yaitu dalam hal berpakaian. Golongan usia tua hingga saat ini masih sering menggunakan pakaian adat Sunda yang terdiri atas baju pangsi dan ikat kepala (untuk laki-laki), sedangkan perempuan memakai kain batik dan memakai baju kebaya. Namun, kebiasaan memakai baju adat Sunda tersebut sudah sedikit memudar bagi warga dengan golongan usia muda.

\section{SIMPULAN DAN SARAN}

\section{Simpulan}

Berdasarkan hasil penelitian yang telah dilakukan, terdapat beberapa kesimpulan seperti berikut ini:

1. Masyarakat Kampung Naga memiliki karakteristik individu yaitu usia yang sebagian besar dewasa tua ( $>35$ tahun). Masyarakat yang berada pada golongan usia dewasa tua memiliki tugas adat untuk menjaga kampung sehingga mereka harus menetap di dalam wilayah kampung. Selain itu, hal ini terjadi karena masyarakat yang berusia remaja (13-18 tahun) dan dewasa awal (19-35 tahun), banyak yang telah merantau ke luar Kampung Naga untuk kepentingan pekerjaan, dan individu yang telah menikah diharuskan untuk menetap di luar Kampung Naga karena keterbatasan lahan sehingga tidak memungkinkan lagi untuk mendirikan bangunan rumah. Jenis kelamin antara laki-laki dan perempuan di Kampung Naga tidak memiliki perbedaan yang signifikan, jumlah laki-laki yaitu 147 jiwa dan jumlah perempuan yaitu 146 jiwa. Sebagian besar masyarakat Kampung Naga memiliki tingkat pendidikan yang rendah, yaitu hanya tamatan SD. Hal tersebut karena kurangnya sarana dan prasarana pendidikan di wilayah Kampung Naga dan terbatasnya perekonomian masyarakat Kampung Naga. Sebagian besar masyarakat Kampung Naga berprofesi sebagai petani karena pekerjaan tersebut merupakan pekerjaan turun-temurun dari leluhur Kampung Naga, dan lahan pertanian yang luas di sekitar Kampung Naga.

2. Ketaatan masyarakat Kampung Naga terhadap adat di Kampung Naga, termasuk ke dalam golongan kuat. Hal ini terjadi karena masyarakat Kampung Naga masih berpegang teguh terhadap adat istiadat yang telah diturunkan oleh para karuhun atau leluhur mereka. Hal tersebut dapat dilihat dari kekonsistenan masyarakat Kampung Naga dalam melaksanakan acara-acara adat, dari zaman dahulu hingga saat ini tidak ada perubahan dalam hal tata cara pelaksanaan acara-acara adat.

3. Dengan menggunakan karakteritik individu yaitu usia responden sebagai variabel kontrol, peran lembaga adat memiliki pengaruh yang lebih besar terhadap responden dengan golongan usia tua.

4. Peran lembaga adat dalam memimpin ritual adat dan keagamaan, memberikan informasi, memelihara warisan leluhur, dan menjaga alam yang semakin tinggi, memiliki pengaruh signifikan terhadap peningkatan perilaku masyarakat Kampung Naga dalam melestarikan budaya.

\section{Saran}

Berdasarkan simpulan penelitian yang diperoleh, peneliti memiliki beberapa saran yang diajukan antara lain:

1. Peran lembaga adat di Kampung Naga dalam hal menyosialisasikan kebudayaan serta adat istiadat sebaiknya lebih ditingkatkan untuk warga Kampung Naga pada golongan usia muda. Hal 
tersebut dilakukan untuk meningkatkan ketaatan warga Kampung Naga dalam melaksanakan kebudayaan di Kampung Naga dan untuk meningkatkan kepatuhan warga terhadap aturan adat yang berlaku di Kampung Naga.

2. Masyarakat Kampung Naga boleh saja terbuka terhadap dunia luar dan hal-hal baru, namun tetap mempertahankan gaya hidup tradisional melalui kepatuhan mereka terhadap adat istiadat yang berlaku di Kampung Naga agar keberadaan budaya dan perilaku masyarakat dalam melaksanakan kebudayaan tetap berkelanjutan.

\section{DAFTAR PUSTAKA}

Anwar Y, Adang. 2013. Sosiologi untuk Universitas. Bandung [ID]: Refika Aditama

Denis L, Cowen R. 2001. Values, Cultures and Education: An Overview. London: Kagan.

Effendi S, Tukiran. 2012. Metode Penelitian Survei. Jakarta (ID): LP3ES

Hindaryatiningsih N. 2016. Model pewarisan nilai-nilai budaya lokal dalam tradisi masyarakat buton. Jurnal Sosiohumaniora. [Internet]. [Dikutip 2018 September 24]. Volume 18 (Nomor 2): 108-115. Dapat diunduh dari:http://jurnal.unpad.ac.id/sosiohumaniora/ar ticle/view/9228/6473

Kartodirjo S. 1984. Kepemimpinan Dalam Dimensi Sosial. Jakarta [ID]: LP3ES. Khairul Muluk M R. 2006. Desentralisasi dan Pemerintahan Daerah. Jawa timur [ID]: Bayumedia Publishing.

Keraf A.S. 2010. Etika Lingkungan Hidup. Jakarta [ID]: Penerbit Buku Kompas

Koentjaraningrat. 1979. Manusia dan Kebudayaan di Indonesia. Jakarta: Penerbit Djambatan

Ntonzima L dan Bayat MS. 2012. The role of traditional leaders in south africa - a relic of the past, or a contemporary reality. Arabian Journal of Business and Management Review. [Internet]. [Dikutip 2018 November 10]. Volume 1 (Nomor 6): 1-21: Dapat diunduh dari: https://www.oecd.org/derec/unitedkingdom/ 48688822.pdf

Miharja D. 2015. Keberagamaan masyarakat adat cikondang dalam menghadapi modernisasi. Journal of Islamic and Social Studies. [Internet]. [Dikutip 2018 September 24]. Volume 1 (Nomor 1): 1-7. Dapat diunduh dari:
https://ejournal.iainbukittinggi.ac.id/index.php/I slam realitas/article/view/11

Pamungkas AS. 2012. Evaluasi program pembauran etnis sebagai upaya tercapainya efektivitas komunikasi antar etnis. [Skripsi]. Bogor (ID): Institut Pertanian Bogor.

Poerwanto H. 2000. Kebudayaan dan Lingkungan Dalam Perspektif Antropologi. Yogyakarta [ID]: Pustaka Pelajar.

Redfield, R. 1956. Peasant Society and Culture. Chicago: University of Chicago Press

Riswar R. 2013. Hubungan Keaslian Kampung Naga dengan Pembentukan Identitas Masyarakat Adat. [Skripsi]. [ Internet]. [dikutip 14 Juni 2019]. Bogor [ID]: Institut Pertanian Bogor. Dapat diunduh dari :https://repository.ipb.ac.id/jspui/ bitstream/123456789/66062/1/I13rri.pdf

Setiawan IK. 2011. Dampak Sosial Ekonomi dan Sosial Budaya Pemanfaatan Pura Tirta Empul sebagai Daya Tarik Wisata Budaya. [Internet]. [dikutip 2019 Juni 14]. Bali(ID) : Universitas Udayana. Dapat diunduh dari : http://lppm.unud.ac.id/wpcontent/uploads/Dampak-Sosial-Ekonomi-danSosial-Budaya-...-oleh-I-Kt.-Setiawan.pdf

Soekanto S. 2012. Sosiologi sebagai Pengantar. Jakarta [ID]: CV Rajawali

Soemantadiredja A. 2014. Pemimpin Adat dan Pembangunan Partisipatif di Kasepuhan Ciptagelar Sukabumi. [Skripsi]. [Internet]. [dikutip 14 Juni 2019]. Bogor [ID]: Institut Pertanian Bogor. Dapat diunduh dari : https://repository.ipb.ac.id /bitstream/123456789/73444/1/114aso.pdf

Suganda H. 2006. Kampung Naga Mempertahankan Tradisi. Bandung (ID): Kiblat Buku Utama.

[UU] Undang-Undang Republik Indonesia Nomor 06 Tahun 2014 Tentang Pemerintahan Daerah

[UU] Undang-Undang Republik Indonesia Nomor 11 Tahun 2010 Tentang Cagar Budaya

[UU] Undang-Undang Republik Indonesia Nomor 32 Tahun 2009 Tentang Perlindungan dan Pengelolaan Lingkungan Hidup

Walters BB, Sabogal C, Snook LK, Almeida ED. 2005. Constraints and opportunities for better silvicultural practice in tropical forestry : an interdisiplinary approac. [Internet]. [15:55].[diunduh 2019 Mei 28]; 209(2005)3-8. 
Tersedia

pada

www.elsevier.com/locate/geoforum.

Widjaja A.W. 1986. Komunikasi dan Hubungan Masyarakat. Jakarta[ID]: Bina Aksara

Wulansari D. 2009.Sosiologi Konsep dan Teori. Bandung [ID]: Refika Aditama.

Wuradji. 1985. Perilaku kepemimpinan masyarakat pedesaan dalam era pembangunan kasus dua desa di kabupaten sleman daerah istimewa yogyakarta. [Disertasi]. [Internet]. [dikutip 4 Desember 2018]. Bogor [ID]: Institut Pertanian
Bogor.
Dapat
diunduh
dari

http://repository.ipb.ac.id/handle/123456789/1

495 